\title{
ARBUSCULAR MYCORRHIZAL FUNGI IN SEEDLING FORMATION OF BARBADOS CHERRY (Malpighia emarginata D.C.) ${ }^{1}$
}

\author{
EDUARDO MENDONÇA PINHEIRO ${ }^{2}$, CAMILA PINHEIRO NOBRE $^{2} *$ THAYANNA VIEIRA COSTA ${ }^{2}$, ORLANDO $^{2}$ \\ CARLOS HUERTAS TAVARES ${ }^{3}$, JOSÉ RIBAMAR GUSMÃO ARAUJO ${ }^{2}$
}

\begin{abstract}
The use of beneficial microorganisms such as arbuscular mycorrhizal fungi (AMF) may favor both the growth phase and the stabilization of the seedlings after transplantation. The aim of this study was to evaluate the effect of inoculation of different AMF species on the development of Barbados cherry seedlings from herbaceous and semi-hardwood cuttings. Softwood and semi-hardwood cuttings, previously rooted, were planted in $500 \mathrm{ml}$ tubes filled with Plantmax ${ }^{\circledR}$ substrate and inoculated with three species of mycorrhizal fungi (Gigaspora margarita - Gimarg, Claroideoglomus etunicatum - Claetun and Glomus clarum - Glclar) isolated and combined (Gimarg + Claetun, Gimarg + Glclar, Claetun + Glclar and Gimarg + Claetun + Glclar). The statistical design was completely randomized in factorial scheme $2 \times 8$ (two types of cuttings and eight types of inoculation, including control without AMF inoculation) with ten replications. The seedlings were kept in a greenhouse for 100 days and height was measured every 15 days to determine the absolute and relative growth rate (AGR and RGR). At the end of the experiment the seedlings were sacrificed and determined height, fresh and dry shoot mass and root and mycorrhizal colonization rate. The results indicate potential for production of Malpighia emarginata D.C. seedlings inoculated with AMF with tendency to reduce the time for transplanting. The Gimarg + Claetun combination promoted higher rates of absolute growth and height of seedlings from herbaceous cuttings. The species Glomus clarum, isolated or associated with C. etunicatum, promoted higher colonization rates in herbaceous and semi-hardwood seedlings, respectively.
\end{abstract}

Keywords: Inoculation. Mycorrhiza. Vegetative propagation.

\section{FUNGOS MICORRÍZICOS ARBUSCULARES NA FORMAÇÃO DE MUDAS DE ACEROLA (Malpighia emarginata D.C.)}

\begin{abstract}
RESUMO - O uso de microrganismos benéficos como os fungos micorrízicos arbusculares (FMA) pode favorecer tanto a fase de crescimento quanto a estabilização das mudas de espécies frutíferas após transplante. O objetivo do estudo foi avaliar o efeito da inoculação de diferentes espécies de FMA no desenvolvimento de mudas de acerola oriundas de estacas herbáceas e semilenhosas. Estacas herbáceas e semilenhosas, previamente enraizadas, foram coladas em tubetes de $500 \mathrm{ml}$ com substrato Plantmax ${ }^{\circledR}$ e inoculadas com três espécies de fungos micorrízicos (Gigaspora margarita - Gimarg, Claroideoglomus etunicatum - Claetun e Glomus clarum - Glclar) isoladas e combinadas (Gimarg+Claetun, Gimarg+Glclar, Claetun+Glclar e Gimarg+Claetun+Glclar). $\mathrm{O}$ delineamento estatístico utilizado foi inteiramente casualizado, esquema fatorial $2 \times 8$ (dois tipos de estacas e oito tipos de inoculação, incluindo o controle sem FMA) com dez repetições. As mudas foram mantidas em casa de vegetação por 100 dias e altura foi mensurada a cada 15 dias para determinação da taxa de crescimento absoluta e relativa (TCA e TCR). Ao final do experimento as mudas foram sacrificadas e determinadas massa fresca e seca da parte aérea e raízes e taxa de colonização micorrízica. Os resultados indicam potencial para a produção de mudas de Malpigia emarginata D.C. por estacas inoculadas com FMA com tendência à redução do tempo para transplantio. A combinação Gimarg+Claetun promoveu maiores taxas de crescimento absoluto e altura de mudas oriundas de estacas herbáceas. A espécie Glomus clarum, isolada ou associada com $C$. etunicatum promovem maiores taxas de colonização em mudas de origem herbácea e semilenhosas, respectivamente.
\end{abstract}

Palavras-chave: Inoculação. Micorriza. Propagação vegetativa.

\footnotetext{
${ }^{*}$ Corresponding author

${ }^{1}$ Received for publication in $07 / 03 / 2017$; accepted in 01/28/2019.

Paper extracted from the master thesis of the first author.

${ }^{2}$ Postgraduate Program in Agroecology, Universidade Estadual do Maranhão, São Luís, MA, Brazil; eduardomp1979@gmail.com ORCID: 0000-0002-0410-382X, camilaenobre@yahoo.com.br - ORCID: 0000-0001-8137-7456, thayvc25@gmail.com - ORCID: 00000002-5121-5330, gusmaoaraujo50@gmail.com - ORCID: 0000-0002-1430-9717.

${ }^{3}$ Postgraduate Program in Soil Science, Universidade Federal Rural do Rio de Janeiro, Seropédica, RJ, Brazil; ochtavares@gmail.com ORCID:0000-0001-9581-0994.
} 


\section{INTRODUCTION}

Soil microorganisms present potential for interaction with agricultural crops and promote their development (MACHINESKI et al., 2018). Arbuscular mycorrhizal fungi (AMF) (phylum: Glomeromycota) are cited among these benefical organisms. AMF are still mentioned for contributing to a decrease in the utilization of fertilizers, improved plant development and nutrition, shortening of the transplantation period, and increased survival of the seedlings in the field (VIERA et al., 2017). These nutritional effects and consequent plant development are due to the absorption of mineral nutrients, mainly phosphorus, nitrogen and water present in the soil that are captured by an extensive network of hyphae and transported to the plant. In contrast, the organic carbon compounds are transferred to the AMF (REN et al., 2013).

These fungi form one of the oldest and most important symbioses known and their action occurs not only by the absorption of soil nutrients, but also due to an increase in surface absorption and exploration of the soil by fungal hyphae (ZHAO et al., 2015), stimulating plant development, resistance to biotic effects such as pests and disease attack and abiotic effects eg water deficiency and transplantation stress (HEIJDEN et al., 2015; MILLAR; BENNETT, 2016). Several factors influence mycorrhizal symbiosis, including plant species, AMF species, climatic factors, soil fertility, pesticide management and use (ZOU et al., 2013).

Several studies have indicated the beneficial effects of AMF inoculation in fruit seedlings, such as blueberry, olive and pitanga (brazilian cherry) (FARIAS et al., 2014; FERREIRA et al., 2015; DALANHOL et al., 2016). Mango seedlings inoculated with AMF presented rooting after 5-6 months with a colonization rate of $50 \%$ for subsequent grafting process (RAMANATHAN et al., 2016). In the absence of phosphate fertilization, the inoculation of seedlings of carambola (star fruit) with Rhizoglomus clarum promoted the highest increments in the production of dry matter, height and contents of nitrogen, calcium and potassium (VITORAZI FILHO et al., 2017). Machineski et al. (2018) observed that inoculation with AMF improved the initial development of persimmon seedlings. While Boyer et al. (2016), affirmed that the greater the ability to specify the genotypes of strawberries colonized by AMF, the higher will be the understanding of its beneficial effects, mainly on resistance or tolerance to pathogens.

Barbados cherry (Acerola cherry) (Malpighia emarginata D.C.) is a tropical plant (CORRÊA et al., 2017) originating from Central America, although it has spread to the South America due to its adaptability (SILVA; DUARTE; BARROZO, 2016). In Brazil, the plant is widely cultivated, with planted area of approximately 7,200 ha and an average yield of 150,000 tons of fruits/year, being the Northeast region the largest in planted area $(3,100 \mathrm{ha})$ and productivity (96,000 tonnes), with the fruits intended for pulp extraction or natural consumption (CALGARO; BRAGA, 2012). Acerola cherry has great economic and nutritional potential due to its high levels of vitamin $\mathrm{C}$ and low caloric value (SILVA JÚNIOR, 2018). This fruit has great exploration potential due to its rusticity and good adaptation to different soil and climate conditions that have its harvest period in northeastern Brazil between the months of October to May (BATAGLION et al., 2015).

The occurrence of AMF association in the cultivation of acerola cherry in Brazil was initially reported by Chu (1993), but studies on the effect of AMF inoculation with this fruit tree are still scarce. Silva Júnior et al. (2017) evaluated the mycorrhizal colonization in barbados cherry cultures and verified the predominance of Paris type colonization pattern and that the soil phosphorus content may affect the colonization rate and the glomerospores density in the root system. Costa et al. (2001) observed higher growth of acerola plants and shorter incubation time when inoculated with the fungus species Gigaspora margarita and Glomus etunicatum. Balota, Machineski and Stenzel (2011) stated that mycorrhization increases the development of acerola plants in soils with low levels of Phosphorus.

Given the economic importance of acerola culture and the scarcity of current publications on the culture of acerola cherry, especially its interaction with arbuscular mycorrhizal fungi and effects of this symbiosis, the objective of this study was to evaluate the effect of inoculation with different species of arbuscular mycorrhizal fungi on the development of acerola seedlings from herbaceous and semihardwood cuttings.

\section{MATERIAL AND METHODS}

\section{Collection and Preparation of cuttings}

In an orchard located in the municipality of São Luís, Maranhão ( $\left.2^{\circ} 34^{\prime} \mathrm{S}, 44^{\circ} 16^{\prime} \mathrm{O}\right)$, aged over 5 years old, were collected herbaceous and semihardwood cuttings of healthy, vigorous plants with standard red-coloured fruits. At the base of each cutting a bevel cut was made and, at the apex, a straight cut at $1.0 \mathrm{~cm}$ from the last pair of leaves. The cuttings were maintained with two pairs of leaves to avoid water losses and facilitate handling, and the leaves were reduced to half and each stake was maintained with four pairs of buds. The portion buried in the substrate corresponded to two pairs of buds, without leaves.

The cuttings were treated with indole-butyric acid (IBA). IBA was previously dissolved in 
approximately $200 \mathrm{~mL}$ of ethyl alcohol and distilled water $(1 \mathrm{~L})$. The cuttings were immersed in IBA solution for 10 seconds at a dosage of $2000 \mathrm{mg} \cdot \mathrm{L}^{-1}$. After this step, the cuttings were planted in polystyrene trays of 125 cells using Plantmax ${ }^{\circledR}$ for rooting for 60 days.

\section{Isolates of arbuscular mycorrhizal fungi}

AMF inoculants were obtained from the Arbuscular Mycorrhizal Fungi Collection of Embrapa Agrobiologia (COFMEA). Each inoculant consisted of spores, pieces of grass roots used for the multiplication of AMF and hyphae. The selected AMF species were: Claroideoglomus etunicatum Claetun (Código COFMEA A44), Gigaspora margarita - Gimarg (Código COFMEA A1) and Glomus clarum - Glclar (Código COFMEA A5).

\section{Installation and Conduction of the Experiment}

The experiment was installed and conducted in a greenhouse of the Agrarian Sciences Center of the Agronomy Department of the State University of Maranhão, located at Paulo VI campus in São Luís, Maranhão, Brazil. $500 \mathrm{ml}$ tubes with autoclaved Plantmax ${ }^{\circledR}$ substrate $\left(2\right.$ hours, $121^{\circ}$ C) (M.O. 66 g.dm ${ }^{-3}$, pH $8.2 \mathrm{CaCl}_{2}$, P $129 \mathrm{mg} . \mathrm{dm}^{-3}$, K 25.6 $\mathrm{mmol}_{\mathrm{c}} \cdot \mathrm{dm}^{-3}, \mathrm{Ca} 210 \mathrm{mmol}_{\mathrm{c}} \cdot \mathrm{dm}^{-3}, \mathrm{Mg} 119 \mathrm{mmol}_{\mathrm{c}} \cdot \mathrm{dm}^{-}$ ${ }^{3}, \mathrm{H}+\mathrm{Al} 6 \mathrm{mmol}_{\mathrm{c}} \cdot \mathrm{dm}^{-3}$, Na $41.5 \mathrm{mmol}_{\mathrm{c}} \cdot \mathrm{dm}^{-3}$, Al 0 $\mathrm{mmol}_{\mathrm{c}} \cdot \mathrm{dm}^{-3}$, H $6 \mathrm{mmol}_{\mathrm{c}} \cdot \mathrm{dm}^{-3}$ and C $38 \mathrm{mmol}_{\mathrm{c}} \cdot \mathrm{dm}^{-3}$ ) were prepared to receive the rooted cuttings. The inoculation was performed prior to transplanting the cuttings through the opening of a pit and deposition of 20 AMF spores in each tube according to the treatment (1.1 to $2.5 \mathrm{~g}$ of inoculant).

Acerola cherry cuttings of herbaceous and semi-hardwood origin were selected after 60 days of rooting. For each type of cutting, the inoculation of AMF species isolated or together (Gimarg, Claetun, Glclar, Gimarg + Claetun, Gimarg + Glclar, Claetun + Glclar and Gimarg + Claetun + Glclar) was carried out without AMF inoculation). Thus, the experimental design was completely randomized, in a factorial scheme $2 \times 8$ (types of cuttings $\mathrm{x}$ inoculation with and without AMF) with ten replications. The experiment was maintained in a nursery under intermittent nebulization with relative humidity around $80 \%$.

The seedlings were fertigated biweekly with the nutrient solution of Hoagland and Arnon (1950), at $1 \%$ ionic strength, and $\mathrm{N}$ and $\mathrm{K}$ doses were balanced using macronutrient and micronutrient sources: $\quad \mathrm{Ca}\left(\mathrm{NO}_{3}\right)_{24} \cdot \mathrm{H}_{2} \mathrm{O} ; \quad \mathrm{KNO}_{3} ; \quad \mathrm{KH}_{2} \mathrm{PO}_{4}$; $\mathrm{MgSO}_{4} .7 \mathrm{H}_{2} \mathrm{O}$; micronutrients and Fe-EDTA solution.

\section{Evaluation}

Every 15 days, using a millimeter ruler, the plant height was measured and at 100 days after the experiment was installed were evaluated height, shoot dry mass (SDM), root dry mass (RDM) and the mycorrhizal colonization rate.

The collected shoot was weighed to determine fresh mass and then submitted to oven drying with air circulation at $65^{\circ} \mathrm{C}$ for 48 hours. After drying, they were weighed and the dry mass of the shoot expressed in grams. The collected roots were washed in tap water under $0.53 \mathrm{~mm}$ mesh, dried on absorbent paper and weighed to obtain fresh root matter. For evaluation of the colonization rate, $1 \mathrm{~g}$ of root of each sample was collected and conserved in alcohol 50\%. The roots were clarified with $2.5 \% \mathrm{KOH}$, acidified with $1 \% \mathrm{HCl}$ and stained with trypan blue (PHILLIPS; HAYMAN, 1970) and the percentage of mycorrhizal colonization was determined by the method of Giovannetti and Mosse (1980).

\section{Growth analysis}

The functional method of the seedling height was adopted and the data were adjusted by means of regression, deriving from this the growth rates. Thus, among the various models proposed by Hunt (1982), we opted to work with the Richards model for seedling height, based on interactive processes. Data analysis was guided by the analysis of variance. The primary data showed strong heterogeneity among the collections, thus the adjustment of the functions was made after the transformation of data, by means of natural logarithm, in order to minimize the effect of heteroskedasticity (SEARLE; GRUBER, 2017; MEAD; CURNOW; HASTED, 2017).

The selection of the model was based on the significance of coefficients, value of the coefficient of determination $\left(\mathrm{R}^{2}\right)$ in conjunction with the global trend of temporal variation of measured variable. The Richards function, growth (C), absolute growth rate (AGR) and relative growth rate (RGR) were calculated according to the expressions, where $\mathrm{T}=$ time, $e=$ exponential and $a, b, c, d=$ Richards equation coefficients (HUNT, 1982):

$$
\begin{aligned}
& C=a\left(1 \pm e^{(b-c T)}\right)^{-1 / d} \quad(\mathrm{~cm}) \quad \text { (eq. 1) } \\
& \left.A G R=\frac{a C e^{b-c T}}{d} \cdot\left(1 \pm e^{b-c T}\right)^{-(1 / d+1}\right) \\
& R G R=\frac{C e^{b-c T}}{d\left(1 \pm e^{b-c T}\right)} \quad\left(\mathrm{cm} \cdot \mathrm{dia}^{-1}\right) \quad \text { (eq. 2) } \\
& \text { (cm.cm } \left.{ }^{-1} \cdot \mathrm{dia}^{-1}\right) \quad \text { (eq. 3) }
\end{aligned}
$$

Absolute growth rate (AGR) expresses the rate of biomass production per unit time. The relative growth rate (RGR) expresses the biomass production rate per unit of pre-existing material (HUNT, 1982). 


\section{Statistical Analysis}

The data obtained were subjected to tests of normality, homogeneity and analysis of variance, and the averages were compared by the Tukey test at the $5 \%$ probability level. For the analysis, some data were transformed: height $(\log \mathrm{x})$, fresh shoot mass $(\sqrt{ } x)$, dry shoot mass $(\sqrt{ } x+0.25)$ and fresh root mass $(\log x+1)$. The Kruskal-Wallis non-parametric test was used for root dry mass analysis. Statistical analysis of the data was performed using the statistical program ASSISTAT version 7.7 beta (SILVA, 2016). The Program SigmaPlot ${ }^{\circledR} 10.0$ was used for preparation of the graphs.

\section{RESULTS AND DISCUSSION}

The inoculation with AMF and its combinations influenced the height of the acerola cherry seedlings differently according to the type of cuttings (Figure 1a and b). The treatment that allowed the seedlings to reach a greater height at 100 days was the combination Gimarg+Claetun however the cuttings inoculated with Gigaspora margarita reached higher height up to 50 days (Figure 1a). The treatment without AMF inoculation showed average height of seedlings higher than the other treatments, while the lowest heights were observed in the Glomus clarum treatments and in the combination $G$. margarita + G. clarum.
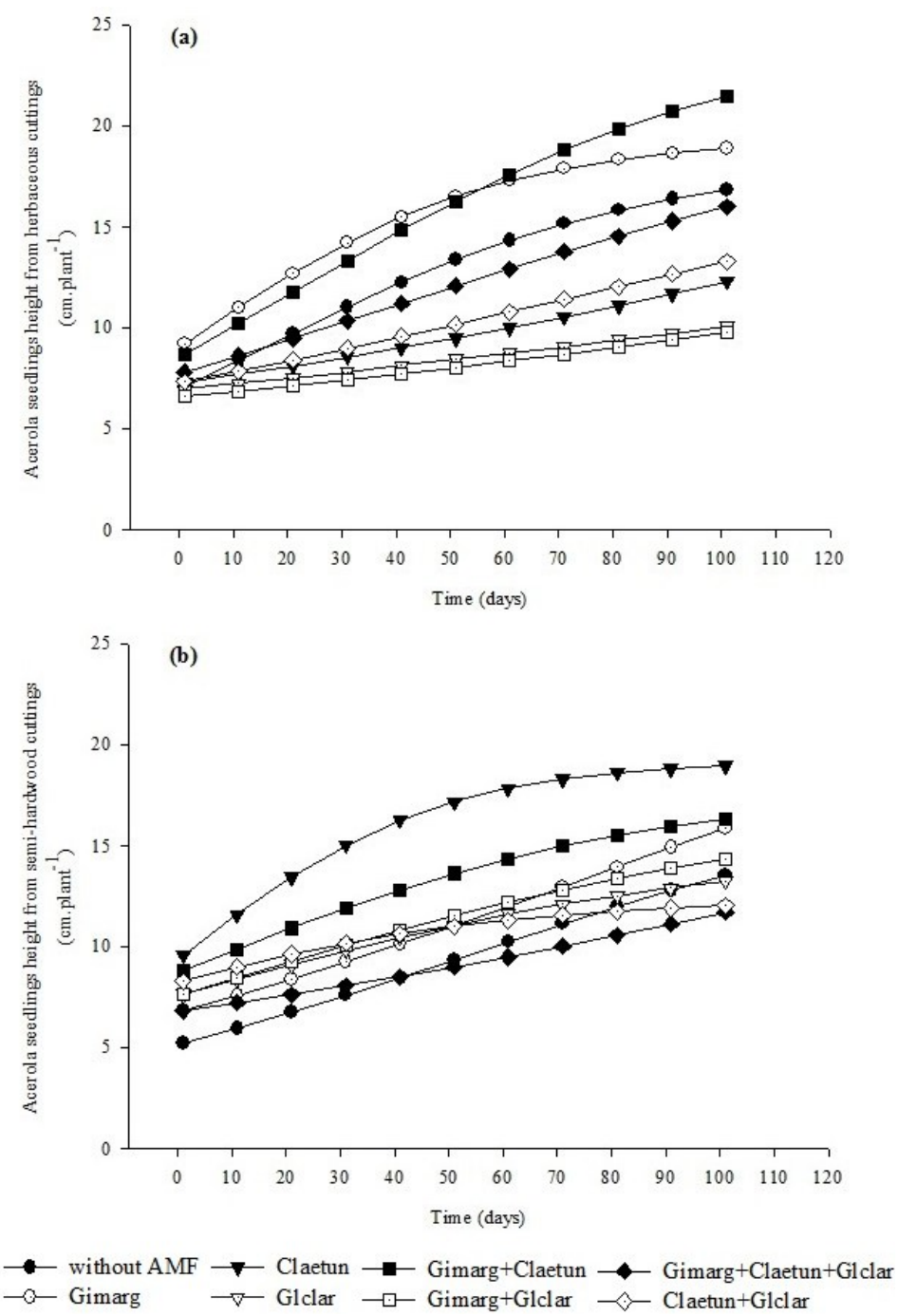

Figure 1. The effect of inoculation with AMF (Gigaspora margarita - Gimarg, Glomus clarum - Glclar and Claroideoglomus etunicatum - Claetu and combinations Gimarg+Claetun, Gimarg+Glclar, Claetun+Glclar and Gimarg+Claetun+Glclar) on height of seedlings of Malphigia emarginata D.C. (cm.plant ${ }^{-1}$ ) from herbaceous cuttings (a) semi-hardwood cuttings (b) during 100 days of experiment.

Seedlings from semi-hardwood cuttings inoculated with $C$. etunicatum attained higher heights, followed by the combination G. margarita + C. etunicatum (Figure 1b). Treatment with the combination of the three species of AMF initially promoted lower heights of seedlings, but at 40 days it outweighed the treatment without inoculation, continuing to grow up to 100 days, being a reflection 
of the low values of mycorrhizal colonization by the short period of plant growth (less than 120 days).

In a study with two genotypes of barbados cherry, the treatments inoculated with Gigaspora margarita and Claroideoglomus etunicatum favored an increase in the height of the seedlings in relation to the control, with each genotype presenting its preferential AMF species (COSTA et al., 2001). Although mycorrhizal symbiosis is considered generalist in relation to hosts (VÁLVY et al., 2016), in the study of Costa et al. (2001), the species of AMF, G. margarita and C. etunicatum were tested isolated or in combinations, verifying the preference between cuttings type and AMF species, indicating that for the same genotype of acerola cherry, the AMF specie may confer different responses according to the vegetative origin of the seedlings.

The relative growth rate for barbados cherry seedlings tends to decline (Figure 2a and b). For herbaceous cuttings, the treatments with the greatest decline of RGR were Gimarg, without AMF, Gimarg + Glclar and the combination of the three AMF species (Figure 2a). Treatments $C$. etunicatum and G. margarita + G. clarum maintained stable RGR.

For seedlings originating from semihardwood cuttings, the RGR of the treatment $G$. margarita $+C$. etunicatum $+G$. clarum remained stable during the evaluated period (Figure $2 b$ ). The other treatments showed a reduction in RGR over time. Several studies indicate that as the plant develops, the RGR tends to decrease due to the maintenance of structures and respiration (NOBRE et al., 2013), increased intraspecific competition for light and nutrients (CONCENÇO et al., 2015) and for this reasons, reflects in the RGR.
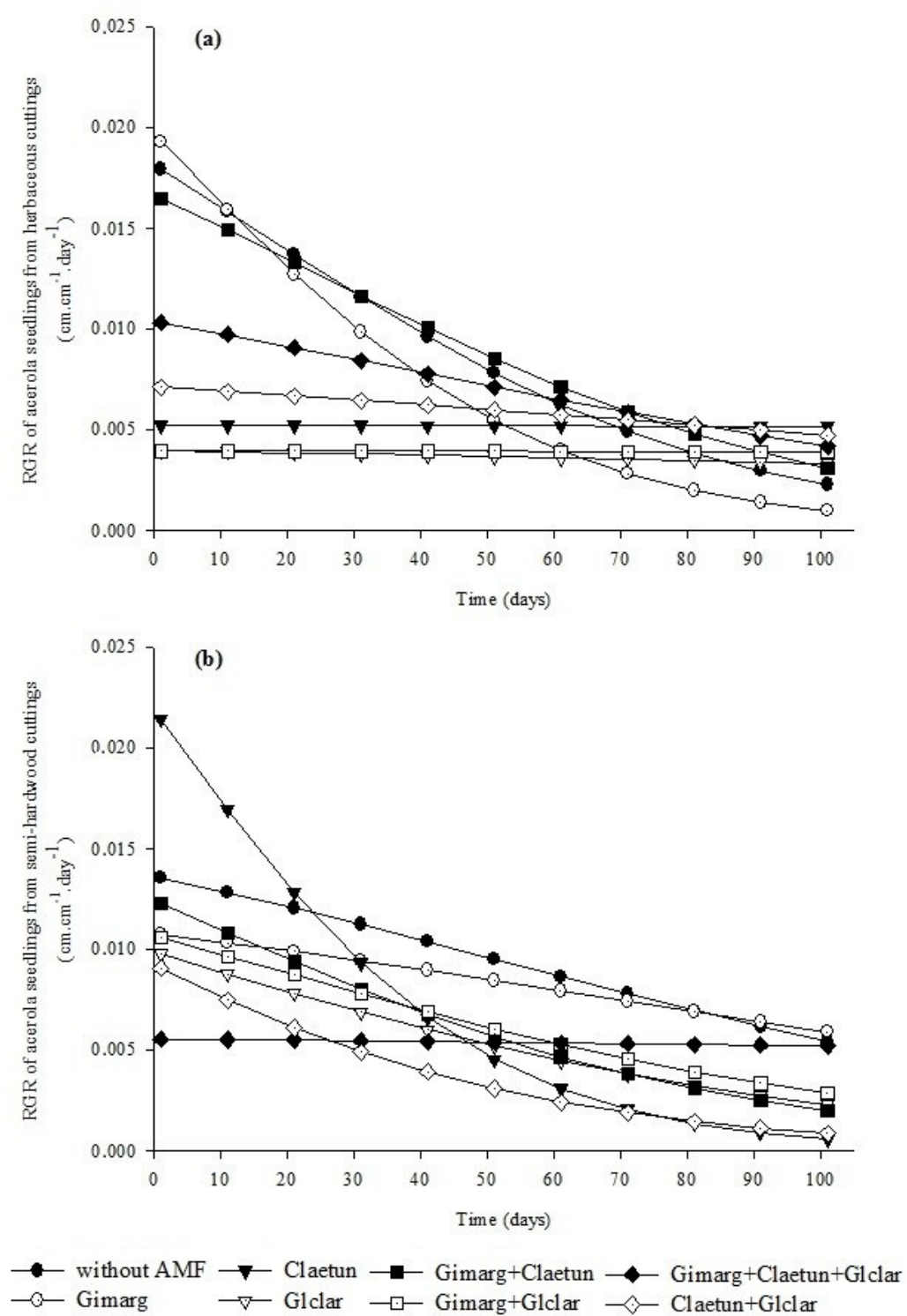

Figure 2. Relative growth rate $\left(\mathrm{cm} \cdot \mathrm{cm}^{-1}\right.$.day $\left.{ }^{-1}\right)$ of Malphigia emarginata D.C. seedlings from herbaceous (a) and semihardwood (b) cuttings inoculated with AMF(Gigaspora margarita-Gimarg, Glomus clarum - Glclar and Claroideoglomus etunicatum-Claetun and combinations Gimarg + Claetun, Gimarg + Glclar, Claetun + Glclar and Gimarg + Claetun + Glclar) for 100 days of experiment. 
The absolute growth rate (AGR) of seedlings from herbaceous cuttings presents a marked decline for treatments without AMF, G. margarita and $G$. margarita $+C$. etunicatum (Figure 3). The other treatments have an increment in the AGR over time, highlighting the treatment Claetun+Glclar, while the treatment with the triple combination indicates a slight decrease of AGR from the 40 day. Even in decline, the Gimarg+Claetun combination is maintained with the highest rates of absolute growth from 22 to 100 days.

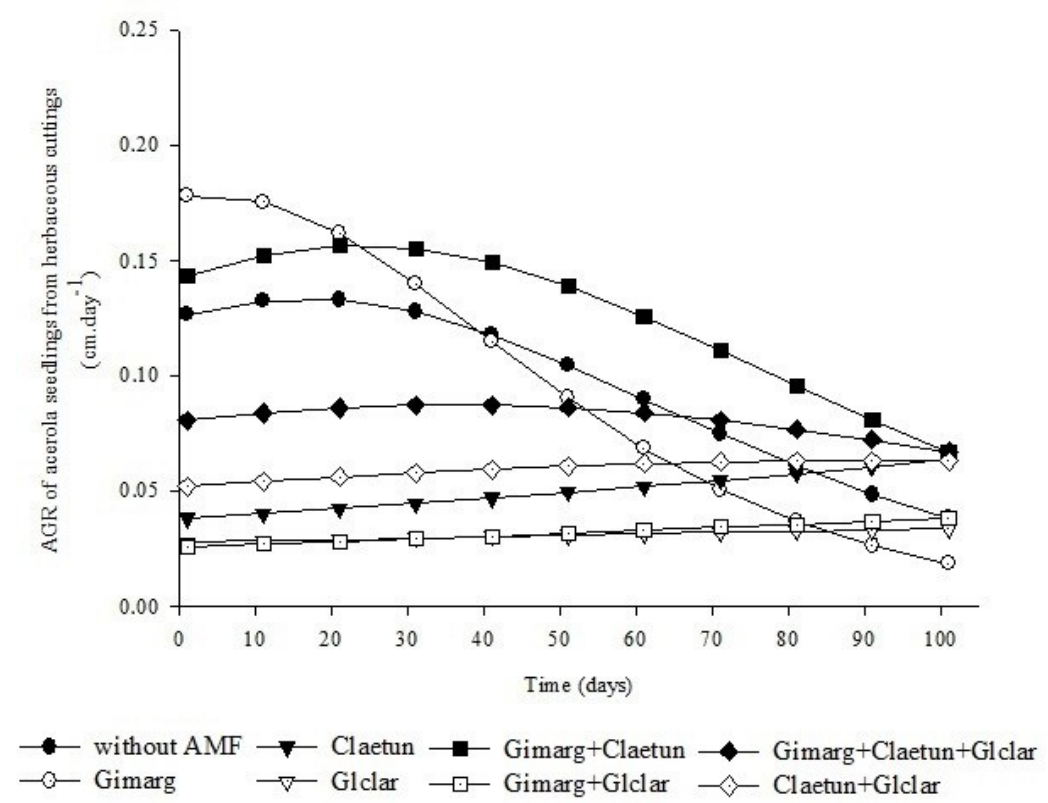

Figure 3. Absolute growth rate $\left(\mathrm{cm}\right.$. day $\left.{ }^{-1}\right)$ of Malphigia emarginata D.C. seedlings which originated from herbaceous cuttings inoculated with AMF (Gigaspora margarita-Gimarg, Glomus clarum - Glclar and Claroideoglomus etunicatumClaetun and combinations Gimarg + Claetun, Gimarg+Glclar, Claetun+Glclar and Gimarg + Claetun + Glclar) for 100 days of experiment.

Evaluating the AGR of barbados cherry seedlings from semi-hardwood cuttings (Figure 4), it was observed that the treatment inoculated with $G$. margarita $+C$. etunicatum $+G$. clarum increases over time from the lower absolute growth rate at the beginning of the experiment to the third largest AGR at 100 days. The Claetun treatment showed the greatest decrease in the AGR over time, while at the end of the experiment, the G. margarita species had the highest absolute growth rate in relation to the other treatments. This effect on the AGR between the two AMF species can be given by the different life strategies of these fungi ( $C$. etunicatum is recognized as a strategist with large production of small spores in short time, while G. margarita presents a K-type strategy, with the formation of few large spores and longer time to generate the propagules), leading to a late action of G. margarita and its contribution to the AGR of barbados cherry at the end of the experimental period. Likewise, the combination of the three AMF species reflected a lower absolute growth rate, probably due to some competition among fungal species.

A study on the growth analysis of urucum (Bixa orellana) inoculated with AMF showed a slight reduction of the AGR between 30 and 60 days and later increase of 60 to 120 days after emergence (BARBIERI et al., 2001). Nobre et al. (2013) while verifying the effect of AMF inoculation on the in vitro growth of Lunularia cruciata, observed that the bryophytes inoculated with the AMF species Glomus proliferum reached the maximum AGR in a shorter time compared to the treatment without inoculation, demonstrating that the mycorrhizal association promotes an increase in the studied growth rate. 


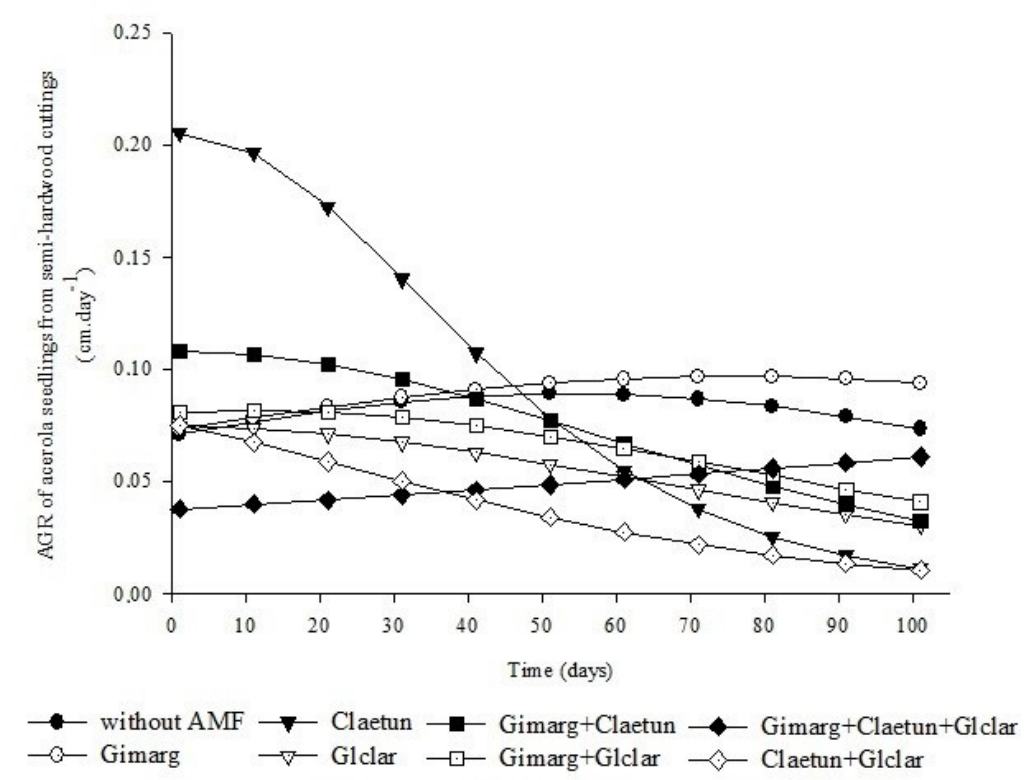

Figure 4. Absolute growth rate $\left(\mathrm{cm}^{-d a y}{ }^{-1}\right)$ of Malphigia emarginata D.C. seedlings originated from semi-hardwood cuttings inoculated with AMF(Gigaspora margarita - Gimarg, Glomus clarum - Glclar and Claroideoglomus etunicatum - Claetun and combinations Gimarg+Claetun, Gimarg+Glclar, Claetum+Glclar and Gimarg+Claetun+Glclar) for 100 days duration of experiment.

The data of these authors corroborate with the results obtained in this work for barbados cherry AGR, even with different plant species, indicating that some isolated or combined AMF species interfere in this growth rate, due to lack of specificity or higher energy cost required for plants to maintain symbiosis. Initially, mycorrhizal symbiosis is a drain for seedlings, but over time, this effect is reduced and the seedlings begin to benefit from the association (FRANÇA et al., 2014).

For seedlings of herbaceous origin, inoculation with Glclar implied lower height, while the combination Gimarg+Claetun favored higher seedling height (Table 1).

Table 1. Effect of the inoculation of arbuscular mycorrhizal fungi (AMF) (Gigaspora margarita-Gimarg, Glomus clarum Glclar and Claroideoglomus etunicatum-Claetun and combinations Gimarg + Claetun, Gimarg + Glclar, Claetun + Glclar and Gimarg + Claetun + Glclar) on the height, shoot dry mass (SDM) and root dry mass (RDM), in the types of herbaceous and semi-hardwood cuttings of Malphigia emarginata D.C. at 100 days after inoculation*.

\begin{tabular}{|c|c|c|c|c|c|c|}
\hline \multirow[t]{2}{*}{ Treatment } & \multicolumn{2}{|c|}{ Height (cm) } & \multicolumn{2}{|l|}{ SDM (g) } & \multicolumn{2}{|l|}{ RDM $(\mathrm{g})^{* *}$} \\
\hline & Herbaceous & $\begin{array}{c}\text { Semi- } \\
\text { hardwood }\end{array}$ & Herbaceous & $\begin{array}{c}\text { Semi- } \\
\text { hardwood }\end{array}$ & Herbaceous & $\begin{array}{c}\text { Semi- } \\
\text { hardwood }\end{array}$ \\
\hline without AMF & $16.41 \mathrm{aAB}$ & $13.65 \mathrm{aA}$ & $0.99 \mathrm{aABC}$ & $0.58 \mathrm{bA}$ & $0.30 \mathrm{AB}$ & $0.19 \mathrm{ABC}$ \\
\hline Gimarg & $19.31 \mathrm{aAB}$ & $15.90 \mathrm{aA}$ & $1.39 \mathrm{aA}$ & $0.68 \mathrm{bA}$ & $0.39 \mathrm{~A}$ & $0.13 \mathrm{ABC}$ \\
\hline Claetun & $12.29 \mathrm{bAB}$ & $18.85 \mathrm{aA}$ & $0.51 \mathrm{bC}$ & $0.98 \mathrm{aA}$ & $0.13 \mathrm{ABC}$ & $0.16 \mathrm{ABC}$ \\
\hline Glclar & $10.15 \mathrm{aB}$ & $12.88 \mathrm{aA}$ & $0.43 \mathrm{aC}$ & $0.68 \mathrm{aA}$ & $0.11 \mathrm{BC}$ & $0.14 \mathrm{ABC}$ \\
\hline Gimarg+Claetun & $20.99 \mathrm{aA}$ & $15.88 \mathrm{bA}$ & $1.27 \mathrm{aAB}$ & $0.92 \mathrm{aA}$ & $0.34 \mathrm{AB}$ & $0.15 \mathrm{ABC}$ \\
\hline Gimarg+Glclar & $12.24 \mathrm{aAB}$ & $14.21 \mathrm{aA}$ & $0.49 \mathrm{aC}$ & $0.70 \mathrm{aA}$ & $0.14 \mathrm{ABC}$ & $0.14 \mathrm{ABC}$ \\
\hline Claetun+Glclar & $13.21 \mathrm{aAB}$ & $12.16 \mathrm{aA}$ & $0.64 \mathrm{aBC}$ & $0.58 \mathrm{aA}$ & $0.14 \mathrm{ABC}$ & $0.06 \mathrm{C}$ \\
\hline Gimarg + Claetun + Glclar & $15.93 \mathrm{aAB}$ & $11.61 \mathrm{bA}$ & $0.82 \mathrm{aABC}$ & $0.66 \mathrm{aA}$ & $0.24 \mathrm{ABC}$ & $0.16 \mathrm{ABC}$ \\
\hline CV\% & 40.45 & 43.89 & 32.14 & 25.32 & 22.14 & 19.17 \\
\hline
\end{tabular}

*Averages followed by the same letter, lowercase in the rows and uppercase in the columns do not differ from each other by the Tukey test at $5 \%$ probability. ** RDM was used for non-parametric Kruskal-Wallis test. 
There are no significant statistical differences among the inoculation treatments for seedlings of semi-hardwood origin, except for RDM in which the treatment Claetun+Glclar presents the lowest values for this variable. For the variables height and SDM, the seedlings of semi-hardwood cuttings presented higher averages in the Claetun treatment compared with the seedlings originated from herbaceous cuttings. Gimarg+Claetum treatment favored higher mean height for seedlings of herbaceous cuttings.

The response to AMF inoculation differs according to the plant species studied. The species of Diospyros virginiana inoculated with $C$. etunicatum showed higher height and dry matter production of shoots and roots (INCESU et al., 2015). Similar results were found in the study of AMF inoculation in Passiflora alata seedlings, observing a positive influence on the growth variables, with higher values in shoot dry matter production and height of plants colonized by $G$. margarita and G. clarum (RITER NETTO et al., 2014). In another study, it was verified that the inoculation of seedlings of olive trees with AMF favors the SDM in relation to noninoculated seedlings (FERREIRA et al. 2015). Oliveira, Alixandre and Miranda (2015) studied the inoculation of the substrate with the isolate $C$. etunicatum and observed that the inoculum promoted the growth and increment of the phytomass of Dipteryx lacunifera Ducke seedlings.

The percentage of colonization by AMF ranged from 32.80 to $64.40 \%$ in herbaceous cuttings and between 32.80 to $54.10 \%$ in herbaceous stake seedlings (Figure 5).

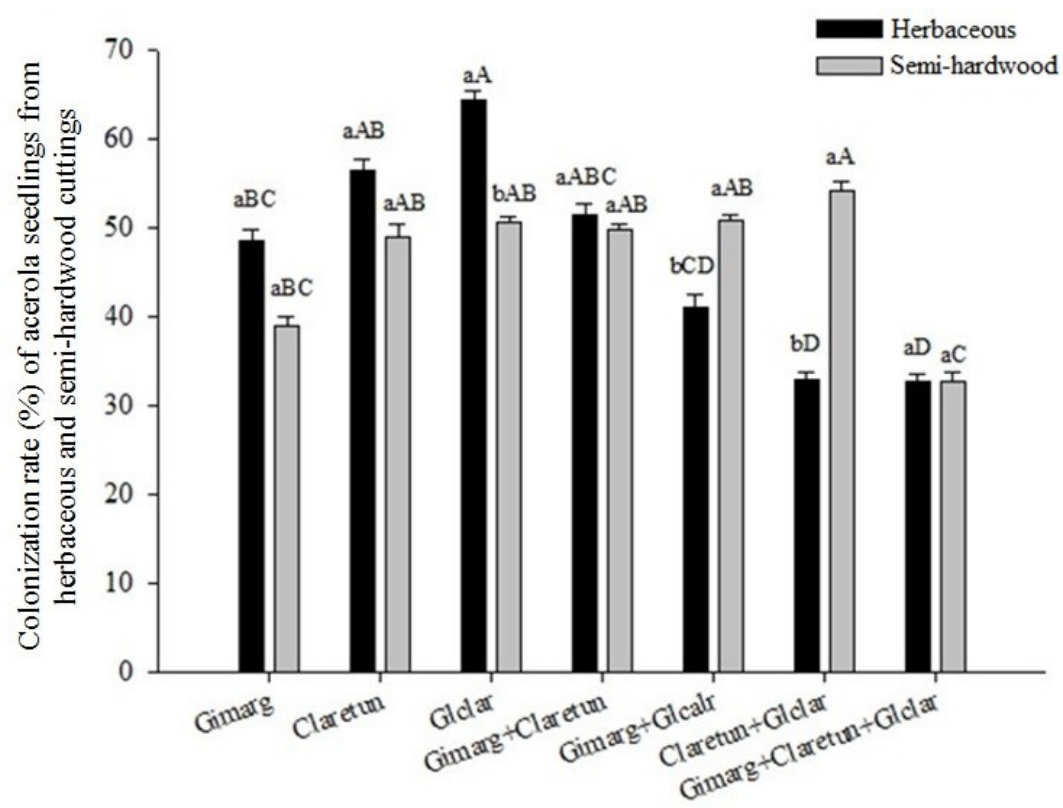

Figure 5. Percentage of root colonization by arbuscular mycorrhizal fungi (Gigaspora margarita-Gimarg, Glomus clarumGlclar and Claroideoglomus etunicatum-Claetun and combinations Gimarg+Claetun, Gimarg+Glclar, Claetun+Glclar and Gimarg+Claetun+Glclar) in seedlings from two types of cuttings of Malphigia emarginata D.C., during 100 days of experiment. Lowercase letters compare different stakes and uppercase letters compare different AMF treatments. Tukey test at $5 \%$.

Statistical differences were observed in mycorrhizal colonization for the species and combinations of AMF, and the inoculation of $G$. clarum was the treatment with the highest percentages of colonization rate $(57.50 \%)$. Analyzing separately, plants originating from herbaceous cuttings presented high mycorrhizal colonization when inoculated with $G$. clarum, compared to the other treatments. In plants originating from semi-hardwood cuttings, colonization in the combination C. etunicatum $+G$. clarum presented superior results to the other treatments.

The high mycorrhizal colonization rate observed in the study can be attributed to the type of inoculum, the density of propagules in the mixtures and the method of application in the substrate, mixing it and keeping it close to the roots. In fact, there is greater efficiency of mycorrhization when the inoculums are constituted by the mixture of soil, roots and fungal propagules (OLIVEIRA JÚNIOR, 2018).

The beneficial effect of AMF on the development of acerola cherry seedlings is reinforced by this work, even with only 20 spores for seedlings inoculation. In the experiments of Silva et al. (2009) utilizing 200 spores per seedling of Passiflora alata Curtis, results similar to those recorded in this study were obtained for growth variables. From the results obtained in this research, 
it was verified that 20 spores are sufficient to inoculate barbados cherry seedlings and to obtain satisfactory results of production and that the species of AMF chosen for this work presented affinity with the genotype of acerola studied.

\section{CONCLUSION}

The inoculation of arbuscular mycorrhizal fungi in Malpighia emarginata D.C. seedlings has effect on the development of cuttings of herbaceous and semi-hardwood origin, stimulating a higher absolute and relative growth rate, besides allowing the seedlings to reach higher height. The species Claroideoglomus etunicatum was presented as a potential inoculant for both types of acerola cherry cuttings. However, carrying out tests with other AMF species, either alone or in combination, extending the evaluation period and installing similar experiments under field conditions may assist in decision making to choose inoculant for the production of more vigorous, healthy acerola seedlings in less time, thus generating greater financial return to the producer.

\section{ACKNOWLEDGEMENT}

The authors express their gratitude to CAPES for granting the post-doctoral fellowship of the second author, the Foundation of Support for Scientific and Technological Research and Development of Maranhão - FAPEMA and the Laboratories of Physiology and Post Harvest and Arthropods and Soil Microbiology- UEMA.

\section{REFERENCES}

BALOTA, E. L.; MACHINESKI, O.; STENZEL, N. M. C. Response of acerola to arbuscular mycorrhizal fungi under different levels of phosphorus. Bragantia, v. 70, n. 1, p. 166-175, 2011.

BARBIERI, D. J. et al. Análise de crescimento de Bixa orellana L. sob efeito da inoculação micorrízica e adubação fosfatada. Revista Brasileira de Plantas Medicinais, v. 13, n. 2, p. 129-138, 2011.

BATAGLiON, G. A. et al. Determination of the phenolic composition from Brazilian tropical fruits by UHPLC-MS/MS. Food Chemistry, v. 180, s/n., p. $280-287,2015$.

BOYER, R. L. et al. The use of arbuscular mycorrhizal fungi to improve strawberry production in coir substrate. Frontiers in Plant Science, v. 7, s/n., p. 1237, 2016.
CAlGARO, M.; BRAGA, M. B. A cultura da acerola. 3. ed. Brasília, DF: EMBRAPA, 2012. 150 p (Coleção Plantar, 69).

CHU, E. Y. Inoculação de fungos micorrízicos arbusculares em plântulas de acerola (Malpighia glabra L.). 1. ed. Belém, PA: Embrapa-CPATU, 1993. 15 p. (Boletim de Pesquisa, 149).

CONCENÇO, G. et al. Crescimento de crambe na presença ou ausência de competição interespecífica. Revista Ceres, v. 62, n. 5, p. 460-468, 2015.

CORRÊA, C. V. et al. Influence of ripening stages on physicochemical characteristics of acerola fruits. Revista de Ciência Agrária, v. 40, n. 4, p. 808-813, 2017.

CostA, C. M. C. et al. Influência de fungos micorrízicos arbusculares sobre o crescimento de dois genótipos de aceroleira (Malpighia emarginata DC). Pesquisa Agropecuária Brasileira, v. 36, n. 6, p. 893-901, 2001.

DALANHOL, S. J. et al. Efeito de fungos micorrízicos arbusculares e da adubação no crescimento de mudas de Eugenia uniflora L., produzidas em diferentes substratos. Revista Brasileira de Fruticultura, v. 38, n. 1, p. 117-128, 2016.

FARIAS, D. H. F. et al. Desenvolvimento de mudas de mirtileiro inoculadas com fungos micorrízicos arbusculares. Revista Brasileira de Fruticultura, v. 36, n. 3, p. 655-663, 2014.

FERREIRA, G. M. R. et al. Fungos micorrízicos arbusculares no desenvolvimento de mudas de oliveira (Olea europaea L.) cultivadas no Sul de Minas Gerais. Revista Brasileira de Ciência do Solo, v. 39, n. 2, p. 361-366, 2015.

FRANÇA, A. C. et al. Crescimento de mudas de cafeeiro inoculadas com fungos micorrízicos arbusculares. Agrária - Revista Brasileira de Ciências Agrárias, v. 9, n. 4, p. 506-511, 2014.

GIOVANNETTI, M.; MOSSE, B. An evaluation of techniques for measuring vesicular arbuscular mycorrhizal infection in roots. New Phytologist, v. 84 , n. 3, p. 489-500, 1980.

HEIJDEN, M. G. A. et al. Mycorrhizal ecology and evolution: the past, the present, and the future. New Phytologist, v. 205, n. 4, p. 1406-1423, 2015.

HUNT, G. Plant Growth Curves: The functional Approach to plant Growth analysis. London: Edward Arnold. 1982. 248 p. 
INCESU, M. et al. Effects on growth of persimmon (Diospyros virginiana) rootstock of arbuscular mycorrhizal fungi species. Turkish Journal of Agriculture and Forestry, v. 39, n. 1, p. 117-122, 2015.

MACHINESKI, G. S. et al. Effects of arbuscular mycorrhizal fungi on early development of persimmon seedlings. Folia Horticulturae, v. 30, n. 1, p. 39-46, 2018.

MILlAR, N. S.; BENNET, A. E. Stressed out symbiotes: hypotheses for the influence of abiotic stress on arbuscular mycorrhizal fungi. Oecologia, v. 182, n. 3, p. 625-641, 2016.

MEAD, R.; CURNOW, R. N.; HASTED, A. M. Statistical methods in agriculture and experimental biology. 3. ed. New York: Chapman and Hall/CRC. 2017. 488 p.

NOBRE, C. P. et al. Biostimulation of inoculation with Glomus proliferum and application of humic acid in the in vitro growth of Lunularia cruciata. Acta Botanica Brasilica, v. 27, n. 4, p. 773-778, 2013.

OLIVEIRA, J. J. F.; ALIXANDRE, T. F.; MIRANDA, J. M. S. Mudas de castanha-do-gurguéia micorrizadas sob níveis de esterco de caprinos. Pesquisa Florestal Brasileira, v. 35, n. 83, p. 189197, 2015.

PHILLIPS, J. M.; HAYAMN, D. S. Improved procedures for clearing roots and staining parasitic and vesicular arbuscular mycorrhizal fungi for rapid assessment of infections. Transactions of British Mycological Society, v. 55, n. 1, p. 158-161, 1970.

OLIVEIRA JÚNIOR, J. Q. Fungos micorrízicos e substratos na formação de mudas de espécies da Mata Atlântica. 2018. 101 f. Tese (Doutorado em Ciências Ambientais e Florestais: Área de Concentração em Silvicultura) - Universidade Federal Rural do Rio de Janeiro, Seropédica, RJ. 2018.

RAMANATHAN. R. et al. Arbuscular Mycorrhizal Fungi in Fruit Crop Seedling Production and Orchard Rejuvenation. In: MOHANDAS. S.; PANNEERSELVAM P. (Eds.). Arbuscular Mycorrhizal Fungi in Fruit Crop Production. New Delhi: Daya Publishing House, 2016. v. 1, cap. 15 , p. $365-381$.

REN, L. et al. Role of arbuscular mycorrhizal network in carbon and phosphorus transfer between plants. Biology and Fertility of Soils, v. 49, n. 1, p. 3-11, 2013.
RITER NETTO, A. F. et al. Efeito de fungos micorrízicos arbusculares na bioprodução de fenóis totais e no crescimento de Passiflora alata Curtis. Revista Brasileira de Plantas Medicinais, v. 16, n. 1, p. 1-9, 2014.

SEARLE, S. R.; GRAUBER, M. H. J. Linear Model. 2rd edn. Hoboken, New Jersey: John Wiley \& Sons. 2017. 655 p.

SILVA, F. A. S. ASSISTAT: Versão 7.7 beta. Disponível em: <http://www.assistat.com>. Acesso em: 20 dez. 2016.

SILVA, P. B.; DUARTE, C. R.; BARROZO, M. A. S. Dehydration of acerola (Malpighia emarginata D.C.) residue in a new designed rotary dryer: Effect of process variables on main bioactive compounds. Food and Bioproducts Processing, v. 98, s/n., p. 62 $-70,2016$.

SILVA, T. F. B. et al. Influência da densidade de fungos micorrízicos arbusculares na produção de maracujazeiro-doce (Passiflora alata Curtis). Revista Caatinga, v. 22, n. 4, p. 1-6, 2009.

SILVA JÚNIOR, J. M. T. da. et al. Morphological pattern of colonization by mycorrhizal fungi and the microbial activity observed in Barbados cherry crops. Ciência Rural, v. 47, n. 12, p. e20160660, 2017.

SILVA JÚNIOR, M. E. Polpa mista de acerola (Malpighia emarginata D.C.) e ceriguela (Spondias purpurea L.) obtida por diferentes métodos de secagem. 2018. 168 f. Dissertação (Mestrado em Ciência e Tecnologia de Alimentos: Área de Concentração em Processamento e Controle de Qualidade de Produtos de Origem Vegetal e Animal) - Universidade Federal Rural de Pernambuco, Recife, 2018.

VÁLVY, K. et al. Community assembly and coexistence in communities of arbuscular mycorrhizal fungi. The ISME Journal, v. 10, n. 10, p. 2341-2351, 2016.

VIERA, W. et al. Native mycorrhizae for improving seedling growth in avocado nursery (Persea americana Mill.). Indian Journal of Science and Technology, v. 10, n. 25, p. 1-13, 2017.

VITORAZI FILHO, J. A. et al. Arbuscular mycorrhizal fungi and phosphate fertilization on star fruit tree seedlings. Revista Brasileira de Ciências Agrárias, v. 12, n. 1, p. 14-19, 2017.

ZHAO, R. et al. Arbuscular mycorrhizal fungi affect the growth, nutrient uptake and water status of maize 
(Zea mays L.) grown in two types of coal mine spoils under drought stress. Applied Soil Ecology, v. 88, s/n., p. 41-49, 2015.

ZOU, Y. N. et al. Mycorrhizal-mediated lower proline accumulation in Poncirus trifoliata under water deficit derives from the integration of inhibition of proline synthesis with increase of proline degradation. PLoS One, v. 8, n. 11, p. e80568, 2013. 